\title{
Feeding habits of mosquitoes (Diptera: Culicidae) in an area of sylvatic transmission of yellow fever in the state of São Paulo, Brazil
}

Luis Filipe Mucci ${ }^{1 *}$, Rubens Pinto Cardoso Júnior ${ }^{2}$, Marcia Bicudo de Paula ${ }^{3}$, Sirle Abdo Salloum Scandar ${ }^{2}$, Márcio Lunardeli Pacchioni ${ }^{4}$, Aristides Fernandes ${ }^{3}$ and Cleide Aschenbrenner Consales ${ }^{5}$

\begin{abstract}
Background: The reintroduction of sylvatic yellow fever in the state of São Paulo after about six decades was confirmed in the Northwestern region in 2000, where in 2008 there also occurred an important epizootic. The purpose of this study was to investigate the feeding habits of culicids potentially involved in the sylvatic transmission of the virus in this region.
\end{abstract}

Methods: Specimens were collected in 24 forested localities at ground level with hand nets and mouth aspirators. Collections were made quarterly between October 2006 and July 2008 during daylight hours. Blood-meal identification was carried out in mosquitoes of the tribes Aedini, Mansoniini and Sabethini. The biotin/avidin sandwich ELISA was employed to determine six source types: bird, bovine, equine, rat, human and monkey.

Results: A total of 24,879 females of the three tribes were obtained, 245 (0.98\%) of which were engorged. The presence of three different blood sources per engorged female was the predominant situation, and included $35.10 \%$ of the total of samples processed. Samples with two or four different sources were represented by $25.31 \%$ and $25.71 \%$, of the specimens, respectively, while just $9.39 \%$ had only one type and $1.22 \%$, five different sources. Aedes scapularis, Ae. serratus (Group), Psorophora albigenu and Ps. ferox were the most abundant species and accounted for about $95 \%$ of the engorged specimens. Of the principal vector species, Haemagogus janthinomys/ capricornii was found with bird, bovine and primate blood. These sources were predominant and alternated top ranking as the most frequent source according to the mosquito species and collection site. In general, primate blood was the most prevalent source.

Conclusions: The human population of the region visits this ecotone frequently, which indicates the need for the periodical assessment of vaccination coverage against yellow fever. The frequency of non-human primate blood source in mosquito species that show minor vector importance in yellow fever virus transmission deserves attention. The eclectic feeding habits and some aspects of the interactions between potential vectors and reservoirs of yellow fever may be associated with the habitat fragmentation characteristic of the region. We recommend that further studies on the capacity and vector competence be performed on secondary vectors in extra-Amazonian region.

Keywords: Feeding habit, Sylvatic yellow fever, Neotropical mosquitoes, Non-human primate, Forest fragmentation

\footnotetext{
* Correspondence: Ifmucci@gmail.com

'Laboratory of Biology and Ecology of Mosquitoes, Superintendence for Endemic Disease Control, State Health Secretariat, Taubaté, São Paulo State, Brazil

Full list of author information is available at the end of the article
}

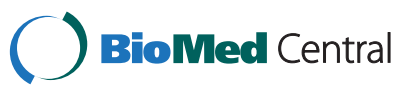

(c) 2015 Mucci et al.; licensee BioMed Central. This is an Open Access article distributed under the terms of the Creative Commons Attribution License (http://creativecommons.org/licenses/by/4.0), which permits unrestricted use, distribution, and reproduction in any medium, provided the original work is properly credited. The Creative Commons Public Domain Dedication waiver (http://creativecommons.org/publicdomain/zero/1.0/) applies to the data made available in this article, unless otherwise stated. 


\section{Background}

The last 20 years have been characterized by the expansion of sylvatic transmission of yellow fever beyond the Amazonian biome in Brazil [1]. This situation represents a serious challenge for public health services, especially in relation to the improvement of surveillance systems, the defining of strategies for the immunization of the susceptible population and the adoption of preventive measures to avoid urban transmission [2-6].

Within this scenario, the hypotheses relating to the introduction and circulation of the virus have been called into question in view of the observation of the distinct aspects of the localities affected in terms of vector fauna, isolation of viruses and the epidemiological or epizootic characteristics of the outbreaks. Generally speaking, nonhuman primates have always been considered the main reservoirs of the virus in the natural environment $[1,7]$. However, the participation of other mammals in the maintenance of the virus and the influence of the double vector-reservoir role of the mosquitoes in the disease cycle are discussed $[1,8,9]$. Furthermore, it was recently suggested a potential mediation of human migrations in virus dispersion based on genetic divergence in Brazilian strains [10].

As to the vector importance of the Culicidae, Haemagogus janthinomys and $\mathrm{Hg}$. leucocelaenus are actually considered the main vectors of the yellow-fever virus in the country [1]. Other species such as $\mathrm{Hg}$. capricornii, $\mathrm{Hg}$. albomaculatus, Hg. spegazzinii, Hg. tropicalis, Sabethes chloropterus, Sa. glaucodaemon, Sa. soperi, Sa. cyaneus, Sa. quasicyaneus, Ae. serratus, Aedes fulvus, Ae. scapularis, Psorophora albipes and Ps. ferox have generally been considered locally important or auxiliary vectors, and for some of these species, viral isolation was recorded only once [11-14].

Studying the Culicidae feeding habits has been proven fundamental in the elucidation of the yellow-fever epidemiological chain [15-17]. The role of some of these vectors as a link in the interchange of viruses between humans and other primates has long since been demonstrated, but it calls for a re-investigation in order to update our knowledge of regional "eco-epidemiologies" and expand research to cover other mosquito species and alternative feeding sources [18]. It is important to bear in mind that the dispersal and availability of vertebrate hosts, including humans and domestic animals, have been undergoing significant changes by virtue of the increase in agricultural and cattleraising activities and the degradation of forest environments, which may be bringing adaptive pressure to bear on the subpopulations of these mosquitoes, raising the possibility of alterations related not only to the characteristics of their niches but also to their vector capacity [19].

In the present study we have sought to investigate the feeding habits of mosquitoes of the Aedini, Mansoniini and Sabethini tribes collected in forest environments adjacent to the main rivers of the northwestern region of São Paulo. The state where the reintroduction of yellow fever was confirmed in 2000 after an absence of about six decades, and the location in 2008 of one of the great epizootic outbreaks recently registered in Brazil [5,20].

Coincidently, these epizootics were simultaneous with the period of the field collection, when there was in the region a series of communications on the deaths of monkeys $(\mathrm{n}=242)$ with clinical and epidemiological confirmation $(n=65)$ and laboratory confirmation $(n=4)$ for yellow fever [21], as well as the occurrence of two human cases in the municipalities of Luiz Antônio and São Carlos, toward the southeast (Figure 1).

\section{Methods}

A total of 24 collection sites were selected in the northwestern region of the state of São Paulo, in 22 municipalities spread over the river basins of the Tietê, São José dos Dourados and Turvo (Figure 1). The area covers the territory of 167 municipalities with a total population of about 3.3 million inhabitants, according to the IBGE census of 2010. The entire study area is included in the "area with vaccine recommendation for yellow fever" determined by the Epidemiological Surveillance Center/Disease Control Coordination of the São Paulo State Health Secretariat. The estimated vaccine coverage for the period of 2003 to 2013 exhibits a predominance of subareas with rates between $60 \%$ and $90 \%$, followed by those between $20 \%$ and $60 \%$, and a few areas with rates over $90 \%$ [22].

The collections were undertaken within forests of secondary succession characteristics, represented by fragments of gallery forest, forested savannah (Cerradão), semi-deciduous seasonal forests and phytophysiognomy of contact between these types [23]. Variations were observed in the herbaceous and bush strata, in the canopy height (between 8 and 25 meters), and in the size of the forest fragments (from 6.50 to 2806.44 hectares) (Additional file 1). With regard to climate, except for the sites in the municipality of Riolândia which presented a humid subtropical climate (Cwa), the other sites were situated in the tropical savanna climate (Aw) in accordance with Köppen's classification, both types having rainy summers and dry winters [23].

In order to cover the four seasons of the year, the collections were made quarterly in the months of October, January, April and July, between October 2006 and July 2007, at the sites located in the basins of the rivers Turvo and São José dos Dourados, and between October 2007 and July 2008 at those in the Tietê River basin. The captures were carried out on two consecutive days at each of the sites, in the period from 09:00 to 15:00 hours, with the participation of three collectors who walked through the interior of the forest making frequent stops 


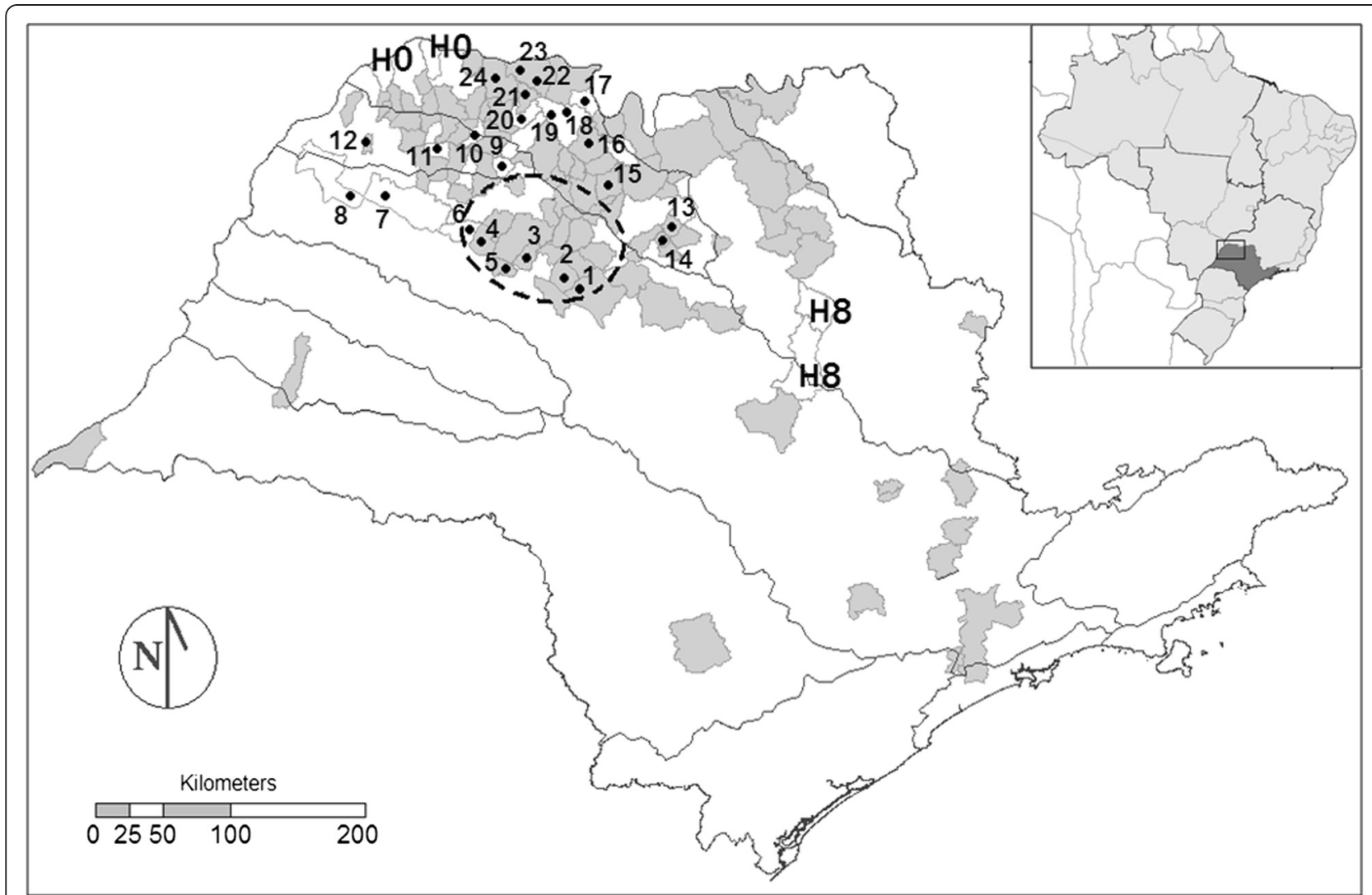

Figure 1 Map of the state of São Paulo showing the collection sites and events related to yellow fever in 2000 and 2008 . Black dots represent the collection sites by number. The larger polygons represent the main river basins of the state. The smaller polygons not filled in indicate municipalities with entomological collections or autochthonous human cases of yellow fever in 2000 (H0) and 2008 (H8). When filled in gray, the area indicates deaths of monkeys in 2008. The dashed line represents the region where the epizootic outbreaks have been confirmed by Adolfo Lutz Institute/State Health Secretariat of São Paulo, Brazil.

to apprehend the specimens by approaching them with a hand-net catcher and mouth aspirator (Castro's capturers). Individual protection equipment was used (a legionnaire's cap, gloves and jacket) to avoid contact between the collectors and the mosquitoes, to ensure that the human blood found in the engorged females was not that of the collectors themselves. The specimens obtained were sacrificed in chloroform vapor and conditioned in entomological boxes each hour, when not engorged. The engorged females were placed individually in $1.5 \mathrm{~mL}$ cryotubes, preserved in the field in thermal boxes with ice and later conserved in a freezer at $-20^{\circ} \mathrm{C}$ until they could be identified and processed.

Identification was undertaken individually to the taxonomic species level, following Consoli and Lourenço-deOliveira [24], Forattini [25] and Lane [26] whereas the name abbreviations used were those of Reinert [27]. A cold table was used for the identification of the frozen material; and the engorged females belonging to the Aedini, Mansoniini and Sabethini tribes were selected for investigation of the blood source. In this study we consider that
Aedes serratus Group includes females of Ae. serratus and Ae. serratus/aenigmaticus.

The technique employed to determine the presence of ingested blood in the abdominal contents was the biotin/avidin sandwich enzyme-linked immunosorbent assay (ELISA) in accordance with the procedures used by Marassá et al. [17]. The six feeding sources tested were: bird, bovine, equine, human, monkey and rat. For counting the number of different blood sources, we considered five major groups by Family level, grouping humans and monkeys, to enable comparison with results of other studies that do not distinguish these two types.

In the remainder of the results, we considered the distinction between the two types of primates as follows: the human and monkey reagent samples were re-submitted to reaction with the IgG1 human subclass, reactivity to which confirmed the presence of human blood without, however, eliminating the presence of monkey blood, which was denominated primates (human + monkey). The samples reactive to human IgG (total) and subclass IgG1, but non-reactive to monkey were considered 
human (exclusively). Samples non-reactive to human IgG1 were considered to contain only monkey blood by the exclusion criterion, which indicates non-human primates (NHP).

\section{Results}

A total of 25,395 mosquitoes of the Aedini, Mansoniini and Sabethini tribes were collected, 24,879 (97.97\%) of which were female and $516(2.03 \%)$ male, belonging to eight genera and 42 species, representing 45 taxa, including specimens identified to the subgenus level (Additional file 2). The females whose abdomens were distended with fresh blood, eggs, or mixed content numbered 358 (1.44\%), 245 (0.98\%) of which, with fresh blood (engorged), were selected and processed. Engorged females (samples) were obtained at 20 of the 24 sites investigated.

Of the principal vector species, only $H g$. janthinomys/ capricornii was found engorged, despite having been less abundant than Hg. leucocelaenus $(\mathrm{n}=147 \times \mathrm{n}=346 \mathrm{fe}-$ males). Of the 845 females of the genus Sabethes, belonging to the following species: Sa. glaucodaemon $(\mathrm{n}=690)$, Sa. albiprivus $(\mathrm{n}=100)$, Sa. gymnothorax $(\mathrm{n}=27)$, Sa. tridentatus $(\mathrm{n}=15)$, Sa. chloropterus $(\mathrm{n}=9)$, Sa. undosus/ fabricii $(\mathrm{n}=3)$ and Sabethes spp. $(\mathrm{n}=1)$ (Additional file 2), only two females of Sa. glaucodaemon presented a distended abdomen, though none was engorged.

Aedes scapularis, Ae. serratus (Group), Ps. albigenu and Ps. ferox were the most abundant species and accounted for about $95 \%$ of the engorged specimens. The rate of engorged females out of all females collected varied according to the collection sites for each species. For $A e$. scapularis the rate varied from 0.20 to $11.54 \%$, for Ae. serratus (Group) from 0.49 to $5.36 \%$ (site 3 with $100 \%$ of the two specimens captured), for Ps. albigenu from 0.25 to 14.29\%, for Ps. ferox from 0.62 to $6.67 \%$ (Table 1) and for less abundant species from 0.14 to $2.27 \%$, except for $A e$. fulvus, which presented only one female collected and engorged (Additional file 3).

Of the 245 females engorged, eight did not react to any type of antibody used (3.27\%). For the others, from one to five different blood sources were identified in each specimen, with predominance of three $(\mathrm{n}=86,35.10 \%)$ and lesser frequencies of five sources $(\mathrm{n}=3,1.22 \%)$. Samples with two $(n=62)$ or four $(n=63)$ different sources represented 25.31 and $25.71 \%$ of the total, respectively, and with only one blood source $(n=23), 9.39 \%$. Among the most abundant species, the percentage for one source was of $11.92 \%$ for Ae. scapularis, $7.37 \%$ for Ps. albigenu, 5.00\% for Ae. serratus (Group) and $11.11 \%$ for Ps. ferox. Only primates, NHP and bovine were identified in isolation. In the remaining samples 18 combinations of different types of blood sources were observed (Table 2).

Primate blood was in general predominant, being found in $94.29 \%$ of the samples $(n=231)$, with $64.50 \%$ for primates $(\mathrm{n}=158), 0.41 \%$ for humans exclusively $(\mathrm{n}=1)$ and $29.39 \%$ for NHP exclusively $(\mathrm{n}=72)$. Bird and bovine were practically equal, being present in 176 (71.84\%) and $172(70.20 \%)$ samples, respectively. Equine blood was observed in 77 specimens $(31.43 \%)$ and rat blood, the least frequent source, in 16 females (6.53\%) (Table 3).

Among the most abundant species, Ps. albigenu presented a larger number of multiple sources, proportionally, than did Ae. scapularis, the majority being of four different origins. The difference between primates and NHP was also greater in Ps. albigenu than in Ae. scapularis, with a greater proportion of co-occurrence of human and monkey for the first specie. Bird blood occurred with greater frequency in Ps. albigenu and Ae. serratus; bovine blood was proportionally most frequent in Ps. ferox and Ae. serratus. Psorophora ferox was also notable for presenting the greatest frequency of NHP blood and the lowest frequency of human blood among the more abundant species (Figure 2). The only specimen of $\mathrm{Hg}$. janthinomys/capricornii presented primate, bird and bovine blood, the most frequent combination among all the samples.

As to the sample distribution by hydrographic basin and collection site (Table 3), the greatest portion of them were obtained in the São José dos Dourados basin $(\mathrm{n}=84)$ and at sites 19 to 24 of the Lower Turvo basin $(n=118)$. Sites with no samples occurred in the basins of the Tietê (4 and 5) and Middle and Upper Turvo (17 and 13, respectively).

In relation to the identification of sources, only rat blood was not found in samples from the Lower Turvo, which presented greater proportions of samples with equine $(\mathrm{n}=51 ; 66.23 \%)$, bovine $(\mathrm{n}=107 ; 62.21 \%)$, bird $(\mathrm{n}=97 ; 52.11 \%)$ and human blood $(\mathrm{n}=77 ; 48.43 \%)$; the frequency of source NHP was greater at these sites, though proportionally lower than the São José dos Dourados basin if the number of collection sites is taken into consideration (Table 3 ).

When the findings from each collection site are assessed, it may be noted that birds, bovines and primates alternated in the position of most frequent source at all the sites. Site 10 is noteworthy mainly for the quantity of samples with NHP and equine blood, and the low frequency of that of birds and humans. A relatively greater abundance of NHP exclusively was also found at site 24, with low human occurrence. Only at site 9 did the samples with human blood exceed the quantity of those from some other blood source. It is noteworthy that the human and bird sources were not detected in samples of the site 8 . Bovine blood was absent only at site 1 , whereas equine blood was identified at 14 of the 20 sites at which engorged females were obtained; rat blood was found in samples from six different localities and non-reactive samples in five. NHP 
Table 1 Number of collected and engorged females by collection site and municipality

\begin{tabular}{|c|c|c|c|c|c|c|c|c|c|c|c|c|c|c|c|c|}
\hline \multirow[t]{3}{*}{ Municipality } & \multirow{3}{*}{$\begin{array}{l}\text { Collection } \\
\text { site }\end{array}$} & \multicolumn{15}{|c|}{ Species } \\
\hline & & \multicolumn{3}{|c|}{ Ae. scapularis } & \multicolumn{3}{|c|}{ Ae. serratus (G) } & \multicolumn{3}{|c|}{ Ps. albigenu } & \multicolumn{3}{|c|}{ Ps. ferox } & \multicolumn{3}{|c|}{ Others } \\
\hline & & Col. & Eng. & $\% \mathrm{E} / \mathrm{C}$ & Col. & Eng. & $\% \mathrm{E} / \mathrm{C}$ & Col. & Eng. & $\% \mathrm{E} / \mathrm{C}$ & Col. & Eng. & $\% \mathrm{E} / \mathrm{C}$ & Col. & Eng. & $\% \mathrm{E} / \mathrm{C}$ \\
\hline Novo Horizonte & 1 & 1505 & 3 & 0.20 & 1 & 0 & 0.00 & 65 & 1 & 1.54 & 22 & 1 & 4.55 & 40 & 0 & 0.00 \\
\hline Sales & 2 & 629 & 7 & 1.11 & 16 & 0 & 0.00 & 15 & 0 & 0.00 & 19 & 0 & 0.00 & 128 & 0 & 0.00 \\
\hline Ubarana & 3 & 44 & 2 & 4.55 & 2 & 2 & 100 & 4 & 0 & 0.00 & 1 & 0 & 0.00 & 521 & 3 & 0.58 \\
\hline Zacarias & 4 & 392 & 0 & 0.0 & 5 & 0 & 0.00 & 15 & 0 & 0.00 & 6 & 0 & 0.00 & 10 & 0 & 0.00 \\
\hline Barbosa & 5 & 115 & 0 & 0.0 & 3 & 0 & 0.00 & 81 & 0 & 0.00 & 2 & 0 & 0.00 & 379 & 0 & 0.00 \\
\hline Buritama & 6 & 226 & 3 & 1.33 & 3 & 0 & 0.00 & 12 & 0 & 0.00 & 5 & 0 & 0.00 & 5 & 0 & 0.00 \\
\hline $\begin{array}{l}\text { Santo Antônio do } \\
\text { Aracanguá }\end{array}$ & 7 & 1125 & 10 & 0.89 & 0 & 0 & 0.00 & 1 & 0 & 0.00 & 1 & 0 & 0.00 & 11 & 0 & 0.00 \\
\hline Pereira Barreto & 8 & 181 & 1 & 0.55 & 1 & 0 & 0.00 & 30 & 0 & 0.00 & 22 & 0 & 0.00 & 8 & 0 & 0.00 \\
\hline Sebastianópolis do Sul & 9 & 828 & 19 & 2.29 & 59 & 0 & 0.00 & 705 & 24 & 3.40 & 58 & 0 & 0.00 & 12 & 0 & 0.00 \\
\hline Valentim Gentil & 10 & 171 & 10 & 5.85 & 58 & 3 & 5.17 & 22 & 1 & 4.55 & 208 & 4 & 1.92 & 3 & 0 & 0.00 \\
\hline São João do Iracema & 11 & 63 & 0 & 0.00 & 495 & 6 & 1.21 & 32 & 2 & 6.25 & 210 & 0 & 0.00 & 5 & 1 & 20.00 \\
\hline Marinópolis & 12 & 674 & 8 & 1.19 & 1 & 0 & 0.00 & 14 & 2 & 14.29 & 5 & 0 & 0.00 & 527 & 4 & 0.76 \\
\hline Monte Azul Paulista & 13 & 152 & 0 & 0.00 & 92 & 0 & 0.00 & 58 & 0 & 0.00 & 96 & 0 & 0.00 & 4 & 0 & 0.00 \\
\hline Paraíso & 14 & 58 & 0 & 0.00 & 32 & 2 & 6.25 & 22 & 2 & 9.09 & 7 & 0 & 0.00 & 4 & 1 & 25.00 \\
\hline Guapiaçu & 15 & 290 & 1 & 0.34 & 48 & 0 & 0.00 & 251 & 0 & 0.00 & 15 & 1 & 6.67 & 6 & 0 & 0.00 \\
\hline Nova Granada & 16 & 50 & 0 & 0.00 & 128 & 0 & 0.00 & 235 & 1 & 0.43 & 41 & 0 & 0.00 & 115 & 2 & 1.74 \\
\hline Orindiuva & 17 & 195 & 0 & 0.00 & 17 & 0 & 0.00 & 1494 & 0 & 0.00 & 9 & 0 & 0.00 & 540 & 0 & 0.00 \\
\hline \multirow[t]{2}{*}{ Palestina } & 18 & 38 & 0 & 0.00 & 5 & 0 & 0.00 & 796 & 2 & 0.25 & 6 & 0 & 0.00 & 47 & 0 & 0.00 \\
\hline & 19 & 281 & 4 & 1.42 & 159 & 1 & 0.63 & 1338 & 18 & 1.35 & 141 & 0 & 0.00 & 142 & 0 & 0.00 \\
\hline Américo de Campos & 20 & 412 & 3 & 0.73 & 144 & 1 & 0.69 & 244 & 6 & 2.46 & 118 & 1 & 0.85 & 15 & 1 & 6.67 \\
\hline \multirow[t]{2}{*}{ Riolândia } & 21 & 52 & 6 & 11.54 & 538 & 3 & 0.56 & 596 & 19 & 3.19 & 279 & 0 & 0.00 & 70 & 0 & 0.00 \\
\hline & 22 & 73 & 2 & 2.74 & 163 & 4 & 2.45 & 292 & 12 & 4.11 & 101 & 1 & 0.99 & 22 & 0 & 0.00 \\
\hline Pontes Gestal & 23 & 794 & 10 & 1.26 & 143 & 0 & 0.00 & 153 & 4 & 2.61 & 80 & 1 & 1.25 & 45 & 0 & 0.00 \\
\hline \multirow[t]{2}{*}{ Cardoso } & 24 & 376 & 20 & 5.32 & 2 & 0 & 0.00 & 20 & 1 & 5.00 & 7 & 0 & 0.00 & 2 & 0 & 0.00 \\
\hline & Total & 8724 & 109 & 1.25 & 2085 & 22 & 1.06 & 6495 & 95 & 1.46 & 1459 & 9 & 0.62 & 2661 & 12 & 0.45 \\
\hline
\end{tabular}

NHP: non-human primate; Col.: females collected, Eng.: females engorged and \%E/C: percentage of females engorged out of all females collected. Aedes serratus (G): Group including Ae. serratus and Ae. serratus/aenigmaticus. Others corresponding to: Ae. fulvus, Ae. terrens, Coquillettidia venezuelensis, Haemagogus janthinomys/capricornii, Mansonia humeralis, Ma. titillans, Psorophora discrucians and Wyeomyia spp.

exclusively was registered at 12 of the 20 localities with samples (Table 3).

\section{Discussion}

The presence of engorged females is associated with microhabitats of resting places and digestion of blood, which do not necessarily coincide [28]. The feeding habit can be modified by geographical variations among distinct subpopulations or by behavioral changes in the same subpopulation within one single reproductive season [29]. Some Culicidae species bite one or more hosts repeatedly during each gonotrophic cycle, while others are less active [25]. There are cases in which this may also be observed within the same species under the influence of meteorological variations, by infection with some parasite or even by the relative size of the specimens
[30-32]. In addition, the influence of the chosen types of collection methods must always be appreciated in the discussion of results [33,34].

In this present study, the only collection technique used was applied at ground level, in forest fragments, the majority of which presented smaller areas compared to studies on fragmented landscapes [23]. The canopy heights of about $70 \%$ of these fragments attained less than fifteen meters (Additional file 1), being considered relatively low as compared to the heights established for the installation of arboreal platforms for collections in Amazonia, where the tops of the trees commonly reach 30 to 40 meters [35]. Nevertheless, some studies conducted in forest environments of the Savannah and Atlantic Forest biomes have shown more flexible behavior on the part of these mosquito species in their selection of the 
Table 2 Number of samples by combinations and numbers of types of blood source

\begin{tabular}{|c|c|c|c|c|c|c|c|c|c|c|c|c|}
\hline \multirow[t]{3}{*}{ Blood Source } & \multicolumn{12}{|c|}{ Species } \\
\hline & \multicolumn{2}{|c|}{ Ae. scapularis } & \multicolumn{2}{|c|}{ Ae. serratus $(\mathrm{G})$} & \multicolumn{2}{|c|}{ Ps. albigenu } & \multicolumn{2}{|c|}{ Ps. ferox } & \multicolumn{2}{|c|}{ Others } & \multicolumn{2}{|c|}{ Total } \\
\hline & $\mathrm{n}$ & $\%$ & $n$ & $\%$ & $n$ & $\%$ & $\mathrm{n}$ & $\%$ & $\mathrm{n}$ & $\%$ & $\mathrm{n}$ & $\%$ \\
\hline Primates & 8 & 7.34 & 0 & 0.00 & 5 & 5.26 & 0 & 0.00 & 0 & 0.00 & 13 & 5.31 \\
\hline Primates + Bird & 22 & 20.18 & 1 & 5.00 & 17 & 17.89 & 0 & 0.00 & 3 & 25.00 & 43 & 17.55 \\
\hline Primates + Bird + Cow & 18 & 16.51 & 6 & 30.00 & 18 & 18.95 & 1 & 11.11 & 3 & 25.00 & 46 & 18.78 \\
\hline Primates + Bird + Horse & 0 & 0.00 & 0 & 0.00 & 2 & 2.11 & 0 & 0.00 & 0 & 0.00 & 2 & 0.82 \\
\hline Primates + Cow + Horse & 0 & 0.00 & 0 & 0.00 & 1 & 1.05 & 0 & 0.00 & 0 & 0.00 & 1 & 0.41 \\
\hline Primates + Bird + Cow + Horse & 9 & 8.26 & 5 & 25.00 & 29 & 30.53 & 0 & 0.00 & 0 & 0.00 & 43 & 17.55 \\
\hline Primates + Bird + Cow + Rat & 4 & 3.67 & 1 & 5.00 & 2 & 2.11 & 0 & 0.00 & 0 & 0.00 & 7 & 2.86 \\
\hline Primates + Cow + Horse + Rat & 1 & 0.92 & 0 & 0.00 & 0 & 0.00 & 0 & 0.00 & 0 & 0.00 & 1 & 0.41 \\
\hline Primates + Bird + Cow + Horse + Rat & 2 & 1.83 & 0 & 0.00 & 1 & 1.05 & 0 & 0.00 & 0 & 0.00 & 3 & 1.22 \\
\hline Human + Bird + Cow + Horse & 1 & 0.92 & 0 & 0.00 & 0 & 0.00 & 0 & 0.00 & 0 & 0.00 & 1 & 0.41 \\
\hline NHP & 2 & 1.83 & 1 & 5.00 & 2 & 2.11 & 0 & 0.00 & 1 & 8.33 & 6 & 2.45 \\
\hline $\mathrm{NHP}+\mathrm{Cow}$ & 7 & 6.42 & 2 & 10.00 & 5 & 5.26 & 2 & 22.22 & 1 & 8.33 & 17 & 6.94 \\
\hline $\mathrm{NHP}+\mathrm{Bird}+\mathrm{Cow}$ & 12 & 11.01 & 2 & 10.00 & 4 & 4.21 & 0 & 0.00 & 0 & 0.00 & 18 & 7.35 \\
\hline $\mathrm{NHP}+$ Bird + Horse & 1 & 0.92 & 0 & 0.00 & 0 & 0.00 & 0 & 0.00 & 0 & 0.00 & 1 & 0.41 \\
\hline $\mathrm{NHP}+\mathrm{Cow}+$ Horse & 12 & 11.01 & 0 & 0.00 & 2 & 2.11 & 3 & 33.33 & 0 & 0.00 & 17 & 6.94 \\
\hline $\mathrm{NHP}+\mathrm{Cow}+$ Rat & 0 & 0.00 & 0 & 0.00 & 1 & 1.05 & 0 & 0.00 & 0 & 0.00 & 1 & 0.41 \\
\hline $\mathrm{NHP}+$ Bird + Cow + Horse & 1 & 0.92 & 2 & 10.00 & 3 & 3.16 & 1 & 11.11 & 1 & 8.33 & 8 & 3.27 \\
\hline $\mathrm{NHP}+$ Bird + Cow + Rat & 4 & 3.67 & 0 & 0.00 & 0 & 0.00 & 0 & 0.00 & 0 & 0.00 & 4 & 1.63 \\
\hline Bird + Cow & 0 & 0.00 & 0 & 0.00 & 1 & 1.05 & 0 & 0.00 & 0 & 0.00 & 1 & 0.41 \\
\hline Cow & 3 & 2.75 & 0 & 0.00 & 0 & 0.00 & 1 & 11.11 & 0 & 0.00 & 4 & 1.63 \\
\hline Cow + Horse & 1 & 0.92 & 0 & 0.00 & 0 & 0.00 & 0 & 0.00 & 0 & 0.00 & 1 & 0.41 \\
\hline 1 source & 13 & 11.93 & 1 & 5.00 & 7 & 7.37 & 1 & 11.11 & 1 & 8.33 & 23 & 9.39 \\
\hline 2 sources & 30 & 27.52 & 3 & 15.00 & 23 & 24.21 & 2 & 22.22 & 4 & 33.33 & 62 & 25.31 \\
\hline 3 sources & 43 & 39.45 & 8 & 40.00 & 28 & 29.47 & 4 & 44.44 & 3 & 25.00 & 86 & 35.10 \\
\hline 4 sources & 19 & 17.43 & 8 & 40.00 & 34 & 35.79 & 1 & 11.11 & 1 & 8.33 & 63 & 25.71 \\
\hline 5 sources & 2 & 1.83 & 0 & 0.00 & 1 & 1.05 & & 0.00 & 0 & 0.00 & 3 & 1.22 \\
\hline Not reactive & 2 & 1.83 & 0 & 0.00 & 2 & 2.11 & 1 & 11.11 & 8 & 66.67 & 8 & 3.27 \\
\hline Total & 109 & 100 & 20 & 100 & 95 & 100 & 9 & 100 & 12 & 100 & 245 & 100 \\
\hline
\end{tabular}

NHP: non-human primate.

Aedes serratus (G): Group including Ae. serratus and Ae. serratus/aenigmaticus. Others correspond to: Ae. fulvus, Ae. terrens, Coquillettidia venezuelensis, Haemagogus janthinomys/capricornii, Mansonia humeralis, Ma. titillans, Psorophora discrucians and Wyeomyia spp.

heights of the tree strata at which they undertake their egg-laying and their feeding on hosts $[16,36]$.

In view of this aspect, it was decided to apply the sampling effort to a horizontal rather than a vertical plane. According to the environmental characteristics of the study area, we considered that the collection technique whereby the collector moves around (allowing the generation of a series of intrusion effects) results in the coverage of a more varied gradient of microhabitats than the stationary technique on canopy platforms. Furthermore, distances of up to 1,100 meters, from the edge to the interior of the forests, were covered.

Despite this, no male specimens of Hg. janthinomys or Hg. capricornii were obtained, which made it impossible to determine which of the two species was more frequent in the area. In previous research undertaken in the same region, the collection of immature forms in the hollow spaces in trees in the municipality of Santa Albertina (SP, Brazil) permitted the identification of males of $H g$. janthinomys, while $\mathrm{Hg}$. capricornii was registered toward the southeast, in the municipality of Araraquara (SP, Brazil) [37,38].

It is worth observing that collection sites with the greatest relative abundances of $\mathrm{Hg}$. janthinomys/capricornii showed a proximity of about 25 kilometers ( 8 to $45 \mathrm{~km}$ ) from the locations of the epizootic outbreaks of Allouatta caraya confirmed in 2008 [14,21]. At these sites, the forest fragments presented the greatest canopy heights (of about 
Table 3 Number of samples by type of blood source, collection point and river basin

\begin{tabular}{|c|c|c|c|c|c|c|c|c|c|c|c|c|c|c|c|}
\hline \multirow[t]{3}{*}{ Blood source } & \multicolumn{15}{|c|}{ River basin/Collection site } \\
\hline & \multicolumn{9}{|c|}{ Tietê } & & \multicolumn{5}{|c|}{ São José dos Dourados } \\
\hline & 1 & 2 & 3 & 4 & 5 & 6 & 7 & 8 & Sub-T & & 9 & 10 & 11 & 12 & Sub-T \\
\hline Primate & 4 & 7 & 7 & 0 & 0 & 1 & 9 & 0 & 28 & & 33 & 2 & 6 & 5 & 46 \\
\hline Human & 0 & 0 & 0 & 0 & 0 & 0 & 0 & 0 & 0 & & 0 & 0 & 0 & 0 & 0 \\
\hline NHP & 0 & 0 & 0 & 0 & 0 & 0 & 0 & 0 & 0 & & 8 & 15 & 2 & 5 & 30 \\
\hline Bird & 4 & 7 & 7 & 0 & 0 & 1 & 9 & 0 & 28 & & 28 & 4 & 6 & 3 & 41 \\
\hline Cow & 0 & 1 & 4 & 0 & 0 & 2 & 7 & 1 & 15 & & 11 & 17 & 7 & 5 & 40 \\
\hline Horse & 0 & 0 & 1 & 0 & 0 & 0 & 3 & 1 & 5 & & 0 & 15 & 3 & 1 & 19 \\
\hline Rat & 0 & 0 & 0 & 0 & 0 & 0 & 0 & 0 & 0 & & 0 & 0 & 0 & 0 & 0 \\
\hline Not reactive & 1 & 0 & 0 & 0 & 0 & 0 & 1 & 0 & 2 & & 2 & 0 & 1 & 3 & 6 \\
\hline Number of Engorged $q$ & 5 & 7 & 7 & 0 & 0 & 3 & 10 & 1 & 33 & & 43 & 18 & 9 & 14 & 84 \\
\hline \multirow[t]{3}{*}{ Blood source } & \multicolumn{13}{|c|}{ River basin/Collection site } & \multirow{3}{*}{\multicolumn{2}{|c|}{ Total }} \\
\hline & \multicolumn{13}{|c|}{ Turvo-Grande } & & \\
\hline & 13 & 14 & 15 & 16 & 17 & 18 & 19 & 20 & 21 & 22 & 23 & 24 & Sub-T & & \\
\hline Primate & 0 & 3 & 1 & 2 & 0 & 2 & 18 & 9 & 22 & 13 & 11 & 3 & 84 & \multicolumn{2}{|l|}{158} \\
\hline Human & 0 & 0 & 0 & 0 & 0 & 0 & 0 & 0 & 0 & 0 & 0 & 1 & 1 & \multicolumn{2}{|l|}{1} \\
\hline NHP & 0 & 0 & 1 & 1 & 0 & 0 & 5 & 3 & 6 & 6 & 4 & 16 & 42 & \multicolumn{2}{|l|}{72} \\
\hline Bird & 0 & 3 & 2 & 3 & 0 & 2 & 22 & 9 & 24 & 14 & 10 & 18 & 107 & \multicolumn{2}{|l|}{176} \\
\hline Cow & 0 & 3 & 2 & 3 & 0 & 2 & 21 & 11 & 24 & 18 & 13 & 20 & 117 & \multicolumn{2}{|l|}{172} \\
\hline Horse & 0 & 0 & 1 & 1 & 0 & 0 & 9 & 5 & 24 & 6 & 6 & 1 & 53 & \multicolumn{2}{|l|}{77} \\
\hline Rat & 0 & 0 & 0 & 0 & 0 & 0 & 6 & 1 & 1 & 3 & 3 & 2 & 16 & \multicolumn{2}{|l|}{16} \\
\hline Not reactive & 0 & 0 & 0 & 0 & 0 & 0 & 0 & 0 & 0 & 0 & 0 & 0 & 0 & \multicolumn{2}{|l|}{8} \\
\hline Number of Engorged $q$ & 0 & 3 & 2 & 3 & 0 & 2 & 23 & 12 & 28 & 19 & 15 & 21 & 128 & \multicolumn{2}{|l|}{245} \\
\hline
\end{tabular}

NHP: non-human primate; $q=$ females.

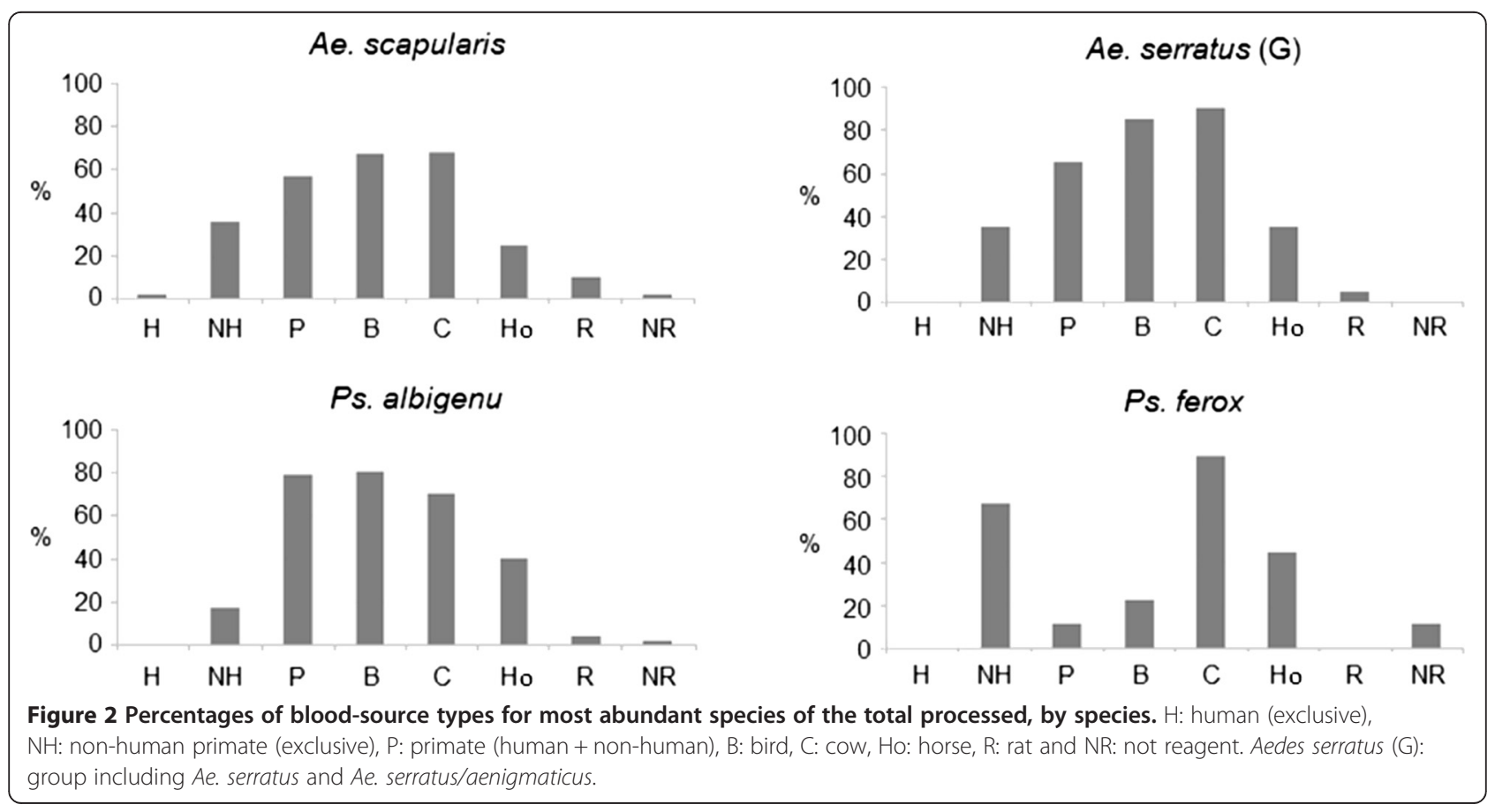


$25 \mathrm{~m})$ and the largest areas of all the collection sites. In that setting the only engorged female of Hg. janthinomys/ capricornii found was one of five specimens caught at site 20 and presented bird, primate and bovine blood, showing eclecticism as well as affinity for human blood, a fact also observed in relation to $\mathrm{Hg}$. janthinomys, but not $\mathrm{Hg}$. capricornii $[15,16]$. The forest fragment at that same location, one of the smallest, having an area of 12.1 hectares, was where Ae. scapularis, Ae. serratus/aenigmaticus and Ps. albigenu were found with NHP blood (Additional file 1).

A synthesis of these results suggests that even though $\mathrm{Hg}$. janthinomys/capricornii is well-adapted to better preserved wild areas, it frequents the degraded, fragmented environment of the region, maintaining its population on the basis of an original re-colonization of better preserved forests. This, together with the functional connectivity of these landscapes, reproduces dispersion systems already reported for other animal groups [39].

Furthermore, the simultaneous finding of a female of $H g$. janthinomys/capricornii engorged with human and monkey bloods and of three other mosquito species with monkey blood in one of the smallest forest fragments indicates the possibility of the transmission of sylvatic yellow-fever in highly modified environments, a behavior also presented by ticks and Brazilian spotted fever in the Atlantic Forest and also discussed in relation to the epizootic outbreaks that occurred in São Paulo state in $2008 / 2009[20,40]$. That is to say, reflecting a process opposite to that of a dilution effect, by which the probability of less specific contacts between vectors and hosts is increased by the fragmentation of their habitat [41]. The high percentage of multiple blood sources found in engorged females of the present study corroborates that model.

The presence of only one blood source type in merely $9.39 \%$ of the specimens is much lower in comparison with the results of other research projects on wild species. Alencar et al. [15] found $60.6 \%$ of the females of $\mathrm{Hg}$. janthinomys with only one blood source in 11 localities of forested environments in five Brazilian states. In four wellpreserved forested localities in central and southeastern Brazil, Alencar et al. [16] found $68.3 \%$ of the females of $\mathrm{Hg}$. leucocelaenus and $66.7 \%$ of those of $\mathrm{Hg}$. capricornii in the same condition. Moreover, dos Santos Silva et al. [42] - in six localities situated in units of environmental conservation, distributed in the Atlantic Forest, Pantanal and Cerrado biomes - found 74.7\% of the females of 15 different Culicidae species with only one blood source.

Day [43] defined three strategies in the feeding behavior of the culicids: directed search, co-habitation and intense eclecticism. Despite Ae. scapularis and Ps. albigenu appearing to come under the third definition, it is supposed to not be an intrinsic characteristic of that species, because it has also been observed among those less frequent ones.
On analyzing patterns of vector/host co-occurrence for a series of localities, Chaves et al. [19] concluded that the contact between a particular mosquito species and a host of a particular bird or mammal species depended more on the presence/absence of that host than on any intrinsic choice on the part of the vector.

The predominance of bird blood was observed by dos Santos Silva et al. [42] in all the 15 species of Culicidae obtained, some of them, such as Ae. fulvus, Ae. scapularis, Ae. serratus, Ps. albigenu, Ps. ferox and Ma. titillans having been investigated in this present study. For $\mathrm{Hg}$. janthinomys, in nine out of 11 localities distributed throughout Brazil, the predominance of bird blood has been registered, with rodent and human blood being of secondary importance [15]. In the state of Rio de Janeiro, Hg. capricornii and $\mathrm{Hg}$. leucocelaenus also present a preference for birds, though in Goiás, rodents, humans and marsupials represent important sources for $\mathrm{Hg}$. leucocelaenus [16].

In the Ribeira Valley, in the southern portion of the state of São Paulo, research in five localities that formed an environmental gradient of agricultural and cattle-raising activity, including residual Atlantic Forest, showed that only in Ae. serratus was bird, bovine and human blood found in the same proportions, with some tendency toward an association with birds in more highly preserved environments. For Ae. scapularis, bovine blood was predominant, followed by equine and human (primate) and for Ps. albigenu and Ps. ferox, human (primate) blood [44,45].

In the light of these findings, it may be inferred that birds serve as constant and frequent hosts for many $\mathrm{Cu}$ licidae species, whereas the use of other blood sources, especially when predominant, depends more on specific situations. The idea that the finding of a particular blood source in female mosquitoes is the result of a balance between adaptive feeding affinity, the opportunity offered by the host and furthermore, on local environmental conditions, as has been observed in North American mosquitoes $[33,34]$.

When the four most abundant species are considered, it may be noted that only in Ps. ferox was bird blood relatively rare, whilst bovine blood was predominant. For Ae. scapularis, Ae. serratus and Ps. albigenu, bovines also represent an important source when the different collection sites are considered. As to the availability of these hosts, it was observed that in all localities where pastures and installations associated with cattle production and management were present, engorged females were obtained with this source. An important aspect to consider is that the invasion of the natural areas by bovine cattle is commonly observed in the state of São Paulo [46]. From an epidemiological approach, the role of large mammals has been discussed not only as to their importance as a reservoir but also in relation to zooprophylaxis and zoopotentiation $[47,48]$. 
As to the primates, the group of greatest interest for the understanding of the wild cycle of yellow fever virus, coincidentally fewer NHP blood samples were detected at the sites closest to the epizootic area (1 to 6 localities) $[14,21]$. Conversely, at location 10 , which corresponded to the single unit of environmental conservation among all sites of collection, the proportion of monkey blood samples was the greatest. Furthermore, no monkey deaths were registered in the municipality (Figure 1), which may constitute evidence of a dilution effect [42].

The fact that the human blood was found in samples from all the collection sites, except one, demonstrates the close proximity of humans to the wild ecotone. In five of these localities the residential estates were adjacent to the forest fragments while at seven sites the farmhouses were located less than 800 meters from the forested areas. Ten of the localities lay beside great reservoirs while the others were situated on the banks of large rivers (Additional file 1). All these areas present attractions commonly used by the local population for recreational, sporting and fishing activities or for extracting clay and sand. The latter situation illustrates the occurrence of the autochthonous human case in São Carlos (SP, Brazil) in 2008 [21].

These aspects reinforce the need to maintain continuous assessments of vaccination coverage [22]. On the other hand, considering the most abundant species collected during this study, it is also recommended that further research should be undertaken to ascertain other aspects of the vector capacity and competence of secondary vectors of the yellow fever virus.

\section{Conclusions}

In this study we observed a considerable proportion of non-human primate blood sources in mosquito species that show minor importance in yellow-fever virus transmission, which suggests that more attention should be dedicated to these species, especially in further studies on their vector competence and capacity.

Our results have also confirmed the proximity to or presence of human beings in the forest fragments of the collection sites at which samples were obtained. This finding indicates that the human population of the region frequents the wild ecotone, which indicates the need for periodic assessments of vaccination coverage against yellow fever in this region of São Paulo state.

Finally, the finding of such highly eclectic feeding habits of mosquitoes in an area of ancient fragmentation in the Mata Atlântica and Brazilian Savannah may serve as a warning about the establishment of new co-evolution processes involving the vectors, hosts and viruses involved in the transmission of yellow fever and other arboviruses, which may consequently challenge us to revise our risk perceptions of these diseases.

\section{Additional files}

\section{Additional file 1: Basic information on collection sites. \\ Additional file 2: Number of collected females and males of Aedini, Mansoniini and Sabethini tribes in the northwestern São Paulo state, Brazil, between 2006 and 2008. \\ Additional file 3: Number of collected and engorged females of the less abundant species.}

\section{Competing interests}

The authors declare that they have no competing interests.

\section{Authors' contributions}

CAC, LFM and RPC Jr. were the lead researchers of this study. RPC Jr., SASS, MLP and CAC designed the study. CAC performed experiments and their analysis. RPC Jr. and MLP coordinated the entomological collections. MBP and AF performed entomological identification and taxonomical discussion. LFM processed the data and results. CAC, LFM, MBP and RPC Jr. participated in the analysis of the results and article writing. All authors read and approved the final manuscript.

\section{Acknowledgments}

The authors sincerely thank professor Almério de Castro Gomes (in memoriam) for the contributions in design of the study, Dr. Ana Maria Marassá for support in the execution of ELISA experiments and the agents team of Superintendência de Controle de Endemias (São Paulo State Health Secretariat) for the support in field collections.

\section{Author details}

'Laboratory of Biology and Ecology of Mosquitoes, Superintendence for Endemic Disease Control, State Health Secretariat, Taubaté, São Paulo State, Brazil. ${ }^{2}$ Regional Service 08, Superintendence for Endemic Disease Control, State Health Secretariat, São José do Rio Preto, São Paulo State, Brazil. ${ }^{3}$ Department of Epidemiology, School of Public Health, University of São Paulo (USP), São Paulo, São Paulo State, Brazil. ${ }^{4}$ Regional Service 09, Superintendence for Endemic Disease Control, State Health Secretariat, Araçatuba, São Paulo State, Brazil. ${ }^{5}$ Diagnostics Section, Pasteur Institute, State Health Secretariat, São Paulo, São Paulo State, Brazil.

Received: 12 September 2014 Accepted: 3 March 2015 Published online: 20 March 2015

\section{References}

1. Vasconcelos PFC. Yellow fever in Brazil: thoughts and hypotheses on the emergence in previously free areas. Rev Saude Publica. 2010;44(6):1144-9.

2. Fortaleza CMCB, Rocha R, Aragão VDN, Almeida RAMB. Syndromic surveillance and the reemergence of yellow fever in São Paulo State, Brazil 2009. J Venom Anim Toxins incl Trop Dis. 2009;15(2):186-9 [http://www. scielo.br/scielo.php?pid=S1678-91992009000200002\&script=sci_arttext]

3. Almeida MAB, Cardoso JC, Santos E, Fonseca DF, Cruz LL, Faraco FJC, et al. Surveillance for yellow fever virus in non-human primates in Southern Brazil, 2001-2011: A tool for prioritizing human populations for vaccination. PLoS Negl Trop Dis. 2014;8(3):e2741.

4. Romano APM, Costa ZGA, Ramos DG, Andrade MA, Jayme V d S, Almeida $M A B$, et al. Yellow fever outbreaks in unvaccinated populations, Brazil, 2008-2009. PLoS Negl Trop Dis. 2014;8(3):e2740.

5. Chiaravalloti Neto F, Dibo MR, Barbosa AAC, Battigaglia M. Aedes albopictus (S) na região de São José do Rio Preto, SP: estudo da sua infestação em área já ocupada pelo Aedes aegypti e discussão de seu papel como possível vetor de dengue e febre amarela. Rev Soc Bras Med Trop. 2002;35(4):351-7.

6. Mascheretti M, Tengan CH, Sato HK, Suzuki A, de Souza RP, Maeda M, et al. Febre amarela silvestre: reemergência de transmissão no Estado de São Paulo, Brasil, 2009. Rev Saude Publica. 2013;47(5):1-9.

7. Araújo FAA, Ramos DG, Santos AL, Passos PHO, Elkhoury ANSM, Costa ZGA, et al. Epizootias em primatas não humanos durante reemergência do vírus da febre amarela no Brasil, 2007 a 2009. Epidemiol Serv Saude. 2011;20(4):527-36.

8. Bugher JC. The mammalian host in yellow fever. In: Strode GK, editor. Yellow fever. New York: McGraw-Hill; 1951. p. 299-384. 
9. Mondet B, Vasconcelos PFC, Travassos da Rosa APA, Travassos da Rosa ES, Rodrigues SG, Travassos da Rosa JFS, et al. Isolation of yellow fever virus from nulliparous Haemagogus (Haemagogus) janthinomys in eastern Amazonia. Vector Borne Zoonotic Dis. 2002:2(1):47-50.

10. Vasconcelos PFC, Bryant JE, Travassos da Rosa APA, Tesh RB, Rodrigues SG, Barrett ADT. Genetic divergence and dispersal of yellow fever virus, Brazil. Emerg Infect Dis. 2004;10(9):1578-84.

11. Vasconcelos PFC, Quaresma JAS, Azevedo RSS, Martins LC. Febre amarela. In: Leão RNQ, Bichara CNC, Fraiha Neto H, Vasconcelos PFC, editors. Medicina Tropical e infectologia na Amazônia. Belém: Samauma Editorial; 2013. p. 549-67.

12. Segura MNO, Castro FC. Atlas de culicídeos na Amazônia brasileira: características especificas de insetos hematófagos da família Culicidae. Belém: Instituto Evandro Chagas; 2007

13. Cardoso J d C, Almeida MAB, Santos ES, Fonseca DF, Sallum MAM, Noll CA, et al. Yellow fever virus in Haemagogus leucocelaenus and Aedes serratus mosquitoes, southern Brazil, 2008. Emerg Infect Dis. 2010;16(12):1918-24.

14. Moreno ES, Rocco IM, Bergo ES, Brasil RA, Siciliano MM, Suzuki A, et al. Reemergence of yellow fever: detection of transmission in the State of São Paulo, Brazil, 2008. Rev Soc Bras Med Trop. 2011;44(3):290-6.

15. Alencar J, Lorosa ES, Dégallier N, Serra-Freire NM, Pacheco JB, Guimarães AE. Feeding patterns of Haemagogus janthinomys (Diptera: Culicidae) in different regions of Brazil. J Med Entomol. 2005;42(6):981-5.

16. Alencar J, Marcondes CB, Serra-Freire NM, Lorosa ES, Pacheco JB, Guimarães AE. Feeding patterns of Haemagogus capricornii and Haemagogus leucocelaenus (Diptera: Culicidae) in two brazilian states (Rio de Janeiro and Goiás). J Med Entomol. 2008;45(5):873-6.

17. Marassá AM, Paula MB, Gomes AC, Consales CA. Biotin-avidin sandwich ELISA with specific human isotypes lgG1 and lgG4 Culicidae mosquito blood meal identification from an epizootic yellow fever area in Brazil. J Venom Anim Toxins incl Trop Dis. 2009;15(4):696-706. http://www.scielo.br/scielo. php?pid=\$1678-91992009000400008\&script=sci_arttext.

18. Soper FL, Penna H, Cardoso E, Serafim Jr J, Frobisher M, Pinheiro J. Yellow fever without Aëdes aegypti: study of a rural epidemic in the Valle do Chanaan, Espirito Santo, Brazil, 1932. Am J Epidemiol. 1933;18(3):555-87.

19. Chaves LF, Harrington LC, Keogh CL, Nguyen AM, Kitron UD. Blood feeding patterns of mosquitoes: random or structured? Front Zool. 2010;7:3. doi:10.1186/1742-9994-7-3.

20. Moreno ES, Spinola RMF, Tengan CH, Brasil RA, Siciliano MM, Coimbra TLM, et al. Yellow fever epizootics in non-human primates, São Paulo state, Brazil, 2008-2009. Rev Inst Med Trop Sao Paulo. 2013;55(1):45-50.

21. Centro de Vigilância Epidemiológica "Prof. Alexandre Vranjac". Casos de febre amarela silvestre em residentes do Estado de São Paulo, 2007-2008. Bol Epidemiol Paul. 2008;5(55):1-8.

22. Ministério da Saúde, Secretaria de Vigilância em saúde. Febre amarela: Aspectos epidemiológicos da febre amarela silvestre e a vigilância intensificada durante o período de monitoramento, Brasil, 2012/2013. Bol Epidemiol. 2014;45(7):1-10.

23. Necchi Júnior O, Branco LHZ, Casatti L, Castilho Noll MSM, Feres RJF, Noll FB, et al. Características da região noroeste do Estado de São Paulo e dos fragmentos florestais remanescentes estudados. In: Necchi Junior O, editor. Fauna e flora de fragmentos florestais remanescentes da região noroeste do Estado de São Paulo. Ribeirão Preto: Holos Editora; 2012. p. 15-36.

24. Consoli RAGB, Oliveira RL. Principais mosquitos de importância sanitária no Brasil. Rio de Janeiro: Editora FIOCRUZ; 1994. p. 228

25. Forattini OP. Culicidologia médica: identificação, biologia, epidemiologia, vol. 2. São Paulo: EDUSP; 2002. p. 864

26. Lane J. Neotropical culicidae, vol. 2. São Paulo: EDUSP; 1953. p. 1112

27. Reinert JF. Revised list of abbreviations for genera and subgenera of Culicidae (Diptera) and notes on generic and subgeneric changes. J Am Mosq Control Assoc. 2001;17(1):51-5.

28. Achee NL, Grieco JP, Rejmankova E, Andre RG, Vanzie E, Polanco J, et al Biting patterns and seasonal densities of Anopheles mosquitoes in Cayo District, Belize, Central America, with emphasis on Anopheles darlingi. J Vector Ecol. 2006;31(1):45-57.

29. Molaei G, Andreadis TG, Armstrong PM, Bueno Jr R, Dennett JA, Real SV, et al. Host feeding pattern of Culex quinquefasciatus (Diptera: Culicidae) and its role in transmission of West Nile virus in Harris County. Texas Am J Trop Med Hyg. 2007;77(1):73-81.
30. Greenberg JA, Lujan DA, Di Menna MA, Wearing HJ, Hofkin BV. Identification of blood meal sources in Aedes vexans and Culex quinquefasciatus in Bernalillo County, New Mexico. J Insect Sci. 2013;13:75.

31. Maciel-de-Freitas R, Sylvestre G, Gandini M, Koella JC. The influence of dengue virus serotype-2 infection on Aedes aegypti (Diptera: Culicidae) motivation and avidity to blood feed. PLoS One. 2013;8(6):e65252.

32. Farjana T, Tuno N. Multiple blood feeding and host-seeking behavior in Aedes aegypti and Aedes albopictus (Diptera Culicidae). J Med Entomol. 2013;50(4):838-46

33. Thiemann T, Nelms B, Reisen WK. Bloodmeal host congregation and landscape structure impact the estimation of female mosquito (Diptera: Culicidae) abundance using dry ice-baited traps. J Med Entomol. 2011:48(3):513-7.

34. Friesen KM, Johnson GD. Evaluation of methods for collecting blood-engorged mosquitoes from habitats within a wildlife refuge. J Am Mosq Control Assoc. 2013;29(2):102-7

35. Pinto CS, Confalonieri UEC, Mascarenhas BM. Ecology of Haemagogus sp. and Sabethes sp. (Diptera: Culicidae) in relation to the microclimates of the Caxiuanã National Forest, Pará, Brazil. Mem Inst Oswaldo Cruz. 2009;104(4):592-8.

36. Alencar J, Morone F, de Mello CF, Dégallier N, Lúcio PS, Serra-Freire NM, et al. Flight height preference for oviposition of mosquito (Diptera: Culicidae) vectors of sylvatic yellow fever virus near the hydroelectric reservoir of Simplicío, Minas Gerais, Brazil. J Med Entomol. 2013;50(4):791-5.

37. Tubaki RM, Menezes RMT, Vesgueiro FT, Cardoso Jr RP. Observations on Haemagogus janthinomys Dyar (Diptera: Culicidae) and other mosquito populations within tree holes in a gallery forest in the northwestern region of São Paulo state, Brazil. Neotrop Entomol. 2010;39(4):664-70.

38. Forattini OP, Gomes AC. Biting activity of Aedes scapularis (Rondani) and Haemagogus mosquitoes in Southern Brazil (Diptera: Culicidae). Rev Saude Publica. 1988:22(2):84-93.

39. Pardini R, de Souza SM, Braga Neto R, Metzger JP. The role of forest structure, fragment size and corridors in maintaining small mammal abundance and diversity in an Atlantic forest landscape. Biol Conserv. 2005;124(2):253-66.

40. Ogrzewalska M, Uezu A, Jenkins CN, Labruna MB. Effect of forest fragmentation on tick infestations of birds and tick infection rates by Rickettsia in the Atlantic forest of Brazil. Ecohealth. 2011;8(3):320-31.

41. Schmidt KA, Ostfeld RS. Biodiversity and the dilution effect in disease ecology. Ecology. 2001;82(3):609-19.

42. dos Santos Silva J, Alencar J, Costa JM, Seixas-Lorosa E, Guimarães AE. Feeding patterns of mosquitoes (Diptera: Culicidae) in six Brazilian environmental preservation areas. J Vector Ecol. 2012;37(2):342-50

43. Day JF. Host-seeking strategies of mosquito disease vectors. J Am Mosq Control Assoc. 2005;21(4 Suppl):17-22.

44. Forattini OP, Gomes AC, Natal D, Kakitani I, Marucci D. Preferências alimentares de mosquitos Culicidae no Vale do Ribeira, São Paulo, Brasil. Rev Saude Publica. 1987:21(3):171-87.

45. Forattini OP, Gomes AC, Natal D, Kakitani I, Marucci D. Preferências alimentares e domiciliação de mosquitos Culicidae no Vale do Ribeira, São Paulo, Brasil, com especial referência a Aedes scapularis e a Culex (Melanoconion). Rev Saude Publica. 1989;23(1):9-19.

46. Duringan $\mathrm{G}$, Siqueira MF, Franco GADC. Threats of the Cerrado remnants of the state of São Paulo, Brazil. Sci Agric (Piracicaba, Braz). 2007;64(4):355-63.

47. Casseb AR, Cruz AV, Jesus IS, Chiang JO, Martins LC, Silva SP, et al. Seroprevalence of flaviviruses antibodies in water buffaloes (Bubalus bubalis) in Brazilian Amazon. J Venom Anim Toxins incl Trop Dis. 2014;20:9. doi:10.1186/1678-9199-20-9.

48. Saul A. Zooprophylaxis or zoopotentiation: the outcome of introducing animals on vector transmission is highly dependent on the mosquito mortality while searching. Malar J. 2003;2:32. 